\title{
Description of the Protective Feature of Oregano Essential Oil Sold as a Commercial Site on Rainbow Trout
}

\author{
Nermin Karaton Kuzgun ${ }^{1 *}$, Sevda Kırbağ ${ }^{2}$ \\ ${ }^{1}$ Munzur University, Fisheries Faculty, Department of Fish Processing, 6200 Tunceli, Turkey \\ ${ }^{2}$ Firat University, Science Faculty, Department of Biology, 23100 Elazig, Turkey \\ nerminkaraton@hotmail.com*iD,skirbag@firat.edu.tr $\mathrm{iD}$ \\ Received date: 08.09.2020, Accepted date: 08.12.2020
}

\begin{abstract}
The essential oil extracted from plants has a shelf-life effect. This study was carried out to determine the difference of natural oregano essential oil, which is considered to be a potential food additive, from commercially available, and its effects on rainbow trout containment by using low amounts of this essential oil. The changes in rainbow trout samples were analyzed by applying commercially available oregano essential oil at a low rate (RT1: 1\% and RT2: 2\%), by looking at the following parameters. When the microbial load, sensory properties, pH, TVB-N, TBA numbers are examined in terms of thyme essential oil application and day relationship, the limit to be consumed in samples with $1 \%$ oregano essential oil is (RT1), on average, between the $3^{\text {rd }}$ and the $6^{\text {th }}$ days. It is between the $3^{\text {rd }}$ and $9^{\text {th }}$ days in the samples applied with $2 \%$ oregano essential oil (RT2). According to the microbial load results, the rainbow trout sample (RT: control) exceeded the consumable limit on day $6^{\text {th }}$ and showed the highest value $(\mathrm{p}<0.05)$. In addition, it has been proven with the TVB-N and TBA values that the samples applied with essential oil are of good quality. In a sense, the shelf lifeis stabilized thanks to the oregano essential oil. As soon as the oregano essential dosage was too much, the protective effect increased.
\end{abstract}

Key Words: Commercial oregano essential oil, food preservation, preservative effect, quality, Rainbow trout

\section{Gökkuşağı Alabalığında Ticari Olarak Satılan Kekik Esansiyel Yağının Koruyucu Özelliğinin Tanımlanması}

Öz

Bitkilerden çıkarılan uçucu yağın raf ömründe etkisi mevcuttur. Bu çalışma, potansiyel bir gıda katkı maddesi olarak kabul edilen doğal kekik uçucu yağının farklılığını ve bu uçucu yağın düşük miktarları kullanılarak gökkuşağı alabalığı muhafazası üzerindeki etkilerini belirlemek amacıyla yapılmıştır. Gökkuşağı alabalığı örneklerindeki değişiklikler, ticari olarak temin edilebilen uçucu kekik yağı düşük bir oranda (RT1:\% 1 ve RT2:\% 2) uygulanarak aşağıdaki parametrelere bakılarak analiz edilmiştir. Kekik uçucu yağı uygulaması ve muhafaza günlerindeki ilişkisi açısından mikrobiyal yük, kimyasal ve duyusal özellikler incelendiğinde bozulmanın yaşandığ 1 günler,\% 1 kekik uçucu yağı içeren numunelerde (RT1) ile \% 2 kekik uçucu yağı ile uygulanan örneklerde 12. günde arasındadır. Mikrobiyal yük sonuçlarına göre gökkuşağı alabalığı numunesi (RT: kontrol) 6. Günde tüketilebilir sınırını aşarak en yüksek değeri göstermiştir (p <0.05). Ayrıca uçucu yağ uygulanan numunelerin TVB-N ve TBA değerlerine göre iyi kalitede olduğu ispatlanmıştır. Diğer anlamda kekik esansiyel yağı sayesinde raf ömrünü stabilize etmişir. Kekik esansiyel yağı konsantrasyonunun çok fazla olması durumunda koruyucu etkisi olmuştur.

Anahtar Kelimeler: Ticari kekik uçucu yağı, gıda koruması, koruyucu etki; kalite, Gökkuşağı alabalığı

\section{INTRODUCTION}

Food rotting involves alteraties in a food product that make it inconsumable from a sensory qualities. Spoilage can be caused by chemical differences (enzymatic, oxidation), physical differences or microbial growing and metabolism in the foodstuff. The main cause of spoilage of raw and minimally processed meat and fish is microbial growth, which 
can manifest itself in the event of textural changes, visible growth (slime), and the appearance of unpleasant odors and unwanted flavors. Because of the short shelf life of fresh fish, the increase in oneday shelf times significantly reduces food losses (Haute et al., 2017). New technologies have emerged to protect fish quality in terms of developing the economy and turning consumers towards preserved foods (Mexis et al., 2009).

Today, the demand for herbal medicinal products is increasing due to their healing therapeutic potential, safe toxicological profile and improved microbial safety (Fraj et al., 2019). The oils, spices and extracts from herbs have been used for centuries to improve the sensory properties and to prolong shelf life of foods. (Botsoglou, 2003; Karabagias et al., 2011; Barreto et al., 2016; Boskovic et al., 2020).

Natural antimicrobial compounds are applied to extend the shelf life of foods. It has been proven by studies that essential oils containing bioactive substances are used as food additives, natural antimicrobial agents and coatings that protect the nutritional values of foods. Derived from Origanum vulgare L., thyme essential oil is recognized for its oxidation-inhibiting and antimicrobial properties (Hosseini et al., 2016).

In recent years, scientific studies in food science and technology have focused on the antimicrobial properties of essential oils in relation to their use in these food bio-preservation systems. Food biopreservation is a frequently accepted system, referred to as a natural practice that can increase shelf life and ensure food microbial safety. (Carmo et al., 2008). In this current topic, $\mathrm{O}$. vulgare essential oil is cited as an interesting source of antimicrobial compounds for use in food preservation (Carmo et al., 2008).

Plant essential oils extracted from thyme $(O$. vulgare) have antimicrobial and antioxidant activities thanks to the phenolic compounds it contains. The studies have demonstrated the effectiveness of films combined with thyme essential oil in inhibiting the microbial growth and synthesis of microbial metabolites was as effective as yeasts and molds, including pathogenic bacteria (Cardoso et al., 2017). Carvacrol, the main thyme component, makes up more than $50 \%$ of the total fat composition. Carvacrol is recognized by the U.S. Food and Drug Administration (FDA) as safe (GRAS) as a food additive that generally demonstrates non-hazardous and non-toxic (United States Federal Regulations
Regulation number 172,515) (Fraj et al., 2019). Oregano essential oil has been investigated for its antimicrobial and antioxidant properties in foods that are sold, such as all small, bovine animals and seafood, both treated and unprocessed. The positive results obtained support the possibility of applying Origanum vulgare essential oil as an alternative antimicrobial agent in food preservation systems.

There are many studies in the literature on the antibacterial and antioxidant properties of thyme essential oil and its subsequent effect on the shelf life of foods. However, there is very little data on the effect of thyme essential oil on the shelf life of fish and fish products (Goulas and Kontaminas, 2007). While some scientists have observed that $O$. vulgare L. extends shelf life (Goulas and Kontominas, 2007; Mexis et al., 2009; Klein et al., 2013; Hosseini et al., 2016), there is a lack of information on both the effects of commercially available oils and their effects on shelf life by keeping their concentrations to the lowest levels (Hosseini et al., 2016). This study was done to detect

This work was done to detect the effects of both the use of oregano essential oil available in the market and its low amount on fish quality.

\section{MATERIAL AND METHODS \\ Raw Material}

Fresh fish (n=36) of the species Oncorhynchus mykiss with a weight of approximately $2.5-3 \mathrm{~kg}$ and their fillets from $1.3-2 \mathrm{~kg}$ and $30-35 \mathrm{~cm}$ tall. were obtained from local fish markets in Elazig. Fishes was brougt to the Firat University Biology laboratory in styrofoam boxes in ice and made into fillets the same day. Oreganium (100\% oil) was purchased from the Kalsec Company (33-03, 864286). The study was conducted in three replicates.

\section{Oncorhynchus mykiss Fillets Preparation and Packaging}

The fillets were made into fillets without skin removing and they washed with plenty of water. The trout fillets were divided in to three groups in total; the control sample without oreganium oil, Oreganium oils at ratio of $1 \%$ and $2 \%$ oil ( $/ \mathrm{w}=$ volume/weight of fish flesh) were used to the trout fillets. Oreganium essential oils was added on both sides of each trout fillet using a micropipette. Then it was massaged with a sterile glove and was immediately started the packaging process. Prepared fish fillets was packaged 
under aerobic conditions. For packing, Ziplock bags made from LDPE plastic material was used and each fillet bag was classified as 50-60 g. They were stored at about $4 \pm 1{ }^{\circ} \mathrm{C}$ until necessary assessments were performed to determine chemical, microbiological and sensorial during shelf life on days $0^{\text {th }}, 3^{\text {th }}, 6^{\text {th }}, 9^{\text {th }}$, and $12^{\text {rd }}$.

\section{Microbiological Assessment}

On each sampling day, each fish fillets $(10 \mathrm{~g}$ each) were taken from each experimental group and transferred into the sterile stomacher bags. Moreover, serial dilutions of homogenized fillets samples were made and then $0.1 \mathrm{~mL}$ of each dilution was added with pipette to the surface of Plate Count Agar (LAB149, 125801/093) plates for evaluation of aerobic bacteria $(\mathrm{AB})$ incubated at $30 \pm 1{ }^{\circ} \mathrm{C}$ for 3 days and psychrophile bacteria (PB) at $5 \pm 1{ }^{\circ} \mathrm{C}$ for 7 days. For lactic acid bacteria, $0.1 \mathrm{ml}$ of each dilution was added with pipette on to the surface of de Man Rogosa Shape agar (LABM093, 123839/254) and the plaques with approximately 2-3 mm MRS medium. After the sampels were cultured to to Potato Dextrose Agar medium (PDA - LABM098, 123328/229) in plaques, incubated at $25 \pm 1{ }^{\circ} \mathrm{C}$ for $4-5$ days, the Yeast and Mould colonies were counted (Harrigan, 1998).

\section{Chemical Assessment}

The $\mathrm{pH}$ values of all samples were measured using a $\mathrm{pH}$ meter (Thermo Scientific Orion 3-Star, UK) (AOAC, 2002). TVB-N (Total volatile basic nitrogen- $\mathrm{mg} 100 \mathrm{~g}^{-1}$ ) analysis was performed according to the method reported by Connell and Shewan, (1979). TBA analysis (Thiobarbituric acidmg MA $\mathrm{kg}^{-1}$ ) of the experimental fillets was determined with the spectro-photometric method by Tarladgis et al., (1960).

\section{Organoleptic Assessment}

The Organoleptic assessment of fish fillets was done by a five-member trained panel from the university. To conduct organoleptic assessment, the samples were baked in a baking at 10 minutes at 180 ${ }^{\circ} \mathrm{C}$. Evaluation has been made in terms of general acceptability. Panellists evaluated general acceptability of the samples on a hedonic scale (9point) ranging from distate extremely (1) to like extremely (9) (Lawless and Heymann, 2010).

\section{Statistical Assessment}

The statistical datas of in this study determined with the IBM SPSS 22.0 soft ware package programe. The statistical comparisons $(\mathrm{p}<0.05)$ were performed amoung all groups storage days with variance analysis (One-way Annova) (Duncan,1955) multiple range test.

\section{RESULTS AND DISCUSSIONS Microbiological Assessment}

Microbiological analysis has shown that oregano essential oil is a potential preservative in reducing the proliferation of microorganisms (aerobic bacteria, psychrophylic bacteria, lactic acid bacteria and yeastmould) that shorten the shelf life of rainbow trout fillets.

If we make a comparison based on ICMSF, (1986), if 7 days CFU / $\mathrm{g}$ is an acceptable value for freshwater fish, we can say that samples prepared by treating oregano essential oil prolong the shelf life in terms of microbiology. Accordingly, rainbow trout fillets treated with $1 \%$ oregano essential oil have extended shelf life until the $9^{\text {th }}$ days, and the $2 \%$ until the $12^{\text {th }}$ days. When the microorganism load of rainbow trout fillets is examined in Tables 1 and 2, it is seen that the essential oil has a positive effect on fish shelf life.

According to this finding; the load of aerobic bacteria in the working groups was determined to be in the level of $3.58 \pm 0.47 \mathrm{log}$ cfu $\mathrm{g}^{-1}$ to $7.28 \pm 0.47$ $\log \mathrm{cfu} \mathrm{g}^{-1}$. The large amount of microorganisms shown on control samples (RT) from day $6^{\text {th }}$ of storage, resulted into significant differences $(\mathrm{p}<0.05)$ in the total aerobic bacteria load when compared with the other part samples treated with oregano essential oil. As shown in Table 1, the load of aerobic bacteria at RT2 on the first day was lower than other rainbow trout samples during the storage period (Initial bacterial load RT; $3.58 \pm 0.47 \log$ cfu $\mathrm{g}^{-1}$ and RT1: $3.72 \pm 0.17 \mathrm{log}$ cfu g ${ }^{-1}$, RT2: $2.75 \pm 0.69 \mathrm{log}$ cfu g ${ }^{-1}$, respectively). Unacceptable aerobic bacteria load was detected on $6^{\text {th }}$ in the control group (RT), and on day 12th in the other groups (RT1 and RT2). The control group had the highest load of aerobic bacteria on day 6th (RT: $7.28 \pm 0.47 \log \mathrm{cfu} \mathrm{g}^{-1}$ ) while the number of bacteria in the other groups reached to the highest value $9^{\text {th }}$ day, $12^{\text {th }}$ day (RT1: $6.20 \pm 0.60 \mathrm{log} \mathrm{cfu} \mathrm{g}^{-1}$, RT2:6.14 $\left.\pm 0.76 \log _{\mathrm{cfug}^{-1}}\right)$. The results show that as the concentration of oregano essential oil used increases (RT1: 1\%,RT2: 2), that is, it decreases the 
microorganism load. The using $(0.8 \% \mathrm{~b} \mathrm{v} / \mathrm{w})$ oregano essential oil slowed the spoilage rate on Goulas and Kontominas (2007)' modified atmosphere packaged and salted sea bream samples. Teixeira et al., (2014) was studied that is of antibacterial effect against microorganisms of garlic essential oil with fish protein films.

We believe that the $4.21 \pm 0.61 \log$ cfu g $^{-1}$ and $3.64 \pm 0.09 \mathrm{log}$ cfu $\mathrm{g}^{-1}$ reduction in psychrophilic load on $0^{\text {th }}$ is the result of essential oil treatment of the trout fillet. The control group had the highest number of psychrotrophic bacteria on day $6^{\text {th }}$ (RT: $6.34 \pm 0.43 \mathrm{log}$ cfu $\mathrm{g}^{-1}$ ) while the number of bacteria in the other groups reached to the highest value in $9^{\text {th }}$ day, $12^{\text {th }}$ days (RT2: $6.80 \pm 0.19 \log$ cfu g $^{-1}$, RT2: $6.84 \pm 0.00 \log$ $\mathrm{cfu}^{-1}$ ) at the end of the storage period respectively. Acording to the statistical analysis, significant differences $(p<0.05)$ were found in the control group and the other groups treatment with oreganium in different concentration for psychrophilic bacteria populations throughout storage. In a study by Cardoso et al., (2017) on the protective effect of active films based on poly (butylene adipate-coterephthalate) treated with oregano essential oil $(0.0$, 2.5, 5.0, 7.5 and $10.0 \mathrm{~g}$ ) on fish fillets, it was found that the development of total coliform, Staphylococcus aureus and psychrotrophic microorganisms decreased and showed an antimicrobial effect except for these film treated with $2.5 \mathrm{~g}$ oregano essential oil. In addition, it has been stated that fish fillets extend the shelf life up to 10 days under cooling. Considering the low concentration (RT1;1\%, RT2; $2 \%$ ) values we used, the data we found are compatible with the study conducted by Coradaso, (2017). In our study, although the concentrations of commercial essential oil were tested as low, the shelf life of the trout samples was stable. Teixeira et al., (2014) was studied that is of antibacterial effect against microorganisms of garlic essential oil with fish protein films

Table 1. Changes in microbial communities (log cfu $\left.\mathrm{g}^{-1}\right)$ during storage of rainbow fillets (RT) and under different concentration treated with oregano essential oils (RT1, RT2)

\begin{tabular}{|c|c|c|c|c|c|c|}
\hline \multicolumn{4}{|c|}{ The Aerobic Bacteria $\left(\log \mathrm{cfu} \mathrm{g}^{-1}\right)$} & \multicolumn{3}{|c|}{ The Psychrophylic Bacteria $\left(\log\right.$ cfu g $\left.^{-1}\right)$} \\
\hline Storage days & RT & RT1 & RT2 & RT & RT1 & RT2 \\
\hline 0 & $3.58 \pm 0.47^{x}$ & $3.72 \pm 0.17^{\mathrm{x}}$ & $2.75 \pm 0.69^{x}$ & $4.21 \pm 0.61^{\mathrm{x}}$ & $3.78 \pm 0.08^{x}$ & $3.64 \pm 0.09^{\mathrm{x}}$ \\
\hline 3 & $5.07 \pm 0.47^{y}$ & $5.14 \pm 0.53^{y}$ & $3.76 \pm 0.16^{\mathrm{y}}$ & $4.85 \pm 0.01^{\mathrm{x}}$ & $4.17 \pm 0.57^{x}$ & $3.77 \pm 0.12^{\mathrm{x}}$ \\
\hline 6 & $7.28 \pm 0.47^{\mathrm{az}}$ & $5.21 \pm 0.45^{\mathrm{abz}}$ & $5.03 \pm 0.67^{\mathrm{bz}}$ & $6.34 \pm 0.43^{\text {ay }}$ & $4.80 \pm 0.10^{\text {by }}$ & $4.88 \pm 0.06^{\text {by }}$ \\
\hline 9 & NA & $6.20 \pm 0.60^{\mathrm{z}}$ & $6.07 \pm 0.52^{\mathrm{z}}$ & NA & $6.22 \pm 0.52^{y}$ & $5.38 \pm 0.08^{y}$ \\
\hline 12 & NA & $7.33 \pm 0.06^{\mathrm{q}}$ & $6.14 \pm 0.76^{\mathrm{q}}$ & NA & $6.80 \pm 0.19^{\mathrm{z}}$ & $6.84 \pm 0.00^{\mathrm{z}}$ \\
\hline 15 & NA & NA & NA & NA & NA & NA \\
\hline
\end{tabular}

RT: The trout samples present not oregano essential oil; RT1: $1 \%$ oregano essential oil was added to the trout samples (volume/weight of fish flesh=v/w), RT2: $2 \%$ oregano essential oil was added to trout samples and oil. The vertical change shows differences between groups. The horizontal change shows differences between days. Significance was defined at $p<0.05$, No significant difference was defined at $\mathrm{p}>0.05$. NA: None acceptability

Table 2. Changes in microbial communities ( $\left.\log \mathrm{cfu}^{-1}\right)$ during storage of carp fillets (RT) and under different concentration treated with oregano essential oils (RT1, RT2)

\begin{tabular}{|c|c|c|c|c|c|c|}
\hline \multicolumn{4}{|c|}{ Lactic Acid Bacteria $\left(\log \mathrm{cfu} \mathrm{g}^{-1}\right)$} & \multicolumn{3}{|c|}{ Yeast and Mould $\left(\log \mathrm{cfu} \mathrm{g}^{-1}\right)$} \\
\hline Storage days & RT & RT1 & RT2 & RT & RT1 & RT2 \\
\hline $\mathbf{0}$ & $3.38 \pm 0.08^{x}$ & $3.96 \pm 0.48^{x}$ & $3.03 \pm 0.79^{x}$ & $3.73 \pm 0.26^{x}$ & $3.12 \pm 0.08^{\mathrm{x}}$ & $3.21 \pm 0.26^{\mathrm{x}}$ \\
\hline 3 & $3.71 \pm 0.23^{\mathrm{x}}$ & $4.01 \pm 0.61^{\mathrm{x}}$ & $3.85 \pm 0.66^{x}$ & $4.99 \pm 0.45^{\mathrm{y}}$ & $4.55 \pm 0.07^{y}$ & $4.59 \pm 0.04^{y}$ \\
\hline 6 & $5.38 \pm 0.69^{y}$ & $5.07 \pm 0.08^{y}$ & $4.70 \pm 0.20^{y}$ & $7.03 \pm 0.43^{\text {ayz }}$ & $4.61 \pm 0.06^{\text {byz }}$ & $5.21 \pm 0.52^{\text {byz }}$ \\
\hline 9 & NA & $4.62 \pm 0.07^{y}$ & $5.81 \pm 0.09^{\mathrm{y}}$ & NA & $6.07 \pm 0.12^{\mathrm{z}}$ & $5.57 \pm 0.02^{\mathrm{z}}$ \\
\hline 12 & NA & $5.89 \pm 0.01^{z}$ & $6.47 \pm 0.66^{\mathrm{z}}$ & NA & $6.47 \pm 0.01^{\mathrm{z}}$ & $6.03 \pm 1.40^{\mathrm{z}}$ \\
\hline 15 & NA & NA & NA & NA & NA & NA \\
\hline
\end{tabular}

RT: The trout samples present not oregano essential oil; RT1: 1\% oregano essential oil was added to the trout samples (volume/weight of fish flesh=v/w), RT2: $2 \%$ oregano essential oil was added to trout samples and oil. The vertical change shows differences between groups. The horizontal change shows differences between days. Significance was defined at $p<0.05$, No significant difference was defined at $\mathrm{p}>0.05$. NA: None acceptability 
The lactic acid bacteria load is shown in Table 2 . The lactic acid bacteria load was determined as $3.38 \pm 0.08 \mathrm{log}$ cfu g $\mathrm{g}^{-1}-5.38 \pm 0.69 \mathrm{log} \mathrm{cfu} \mathrm{g}^{-1}$ in all groups during storage. There is significant different between both groups: RT and RT1, RT2 (on $6^{\text {th }}$ ) (p>0.05). RT1 and RT2 has extended the shelf life of rainbow trout up to 12 th $\left(4.62 \pm 0.07 \log \mathrm{cfu} \mathrm{g}^{-1}\right)$ and 12 th days $\left(6.47 \pm 0.66 \log \mathrm{cfu} \mathrm{g}^{-1}\right)$.

The amount of yeast-mould of all the others samples has been detected during storage period (Table 2.) The yeast-mold population in RT groups was determined as $7.03 \pm 0.43 \mathrm{log} \mathrm{cfu} \mathrm{g}^{-1}$ in 6th day but, RT1; $6.47 \pm 0.001 \log _{\text {cfu g }}{ }^{-1}$ in $12^{\text {th }}$ day, RT2; C2; $6.03 \pm 1.4 \log \mathrm{cfu} \mathrm{g}^{-1}$ in $12^{\text {th }}$ day. This results showed that oregano essential oils have a preservative effect. The significant differences $(p<0.05)$ were found in the control group and the other groups treatment with oregano essential oil in different concentration for yeast-mold count throughout storage. Significant difference of yeast-mold count of samples was determined on some of the storage days $(\mathrm{p}<0.05)$. When compared according to the increasing concentration of essential oil; yeast-mold load in other trout samples treated with oregano essential oil decreased regularly until the 6th day compared to the control group (RT: $7.03 \pm 0.43 \log \mathrm{cfu} \mathrm{g}^{-1}$, RT1: $4.61 \pm 0.06 \mathrm{log} \mathrm{cfu} \mathrm{g}^{-1}$, RT2: $\left.5.21 \pm 0.52 \log \mathrm{cfu} \mathrm{g}^{-1}\right)$.

Oreganum essential oil of Mexis et al., (2009), $(0.4 \%-\mathrm{v} / \mathrm{w})$ was added to rainbow trout samples and packaged with $\mathrm{O}_{2}$ absorbent, thus extending the shelf life by 8 days. Yeast and mold counts were not examined. In our study, concentration-dependent RT1 and RT2 were also prolonged for 12th days under normal cold conditions.

In a study on the investigation of essential oil contents against food spoilage, it was stated that oregano oil prevented the microbiological development of food spoilage bacteria (Carmo et al., 2008; Klein et al., 2013). Gurdian, (2015) stated in his study that oreganum essential oil is evaluation of shelf life of cheeses during refrigerated storage.

\section{Chemical Asessment}

The control and the treated fish samples were evaluated periodically for chemical ( $\mathrm{pH}$; total volatile basic nitrogen-TVB-N; thiobarbituric acid-TBA) characteristics.

The $\mathrm{pH}$ value of control groups was decreased on 6th day (Figure 1). Significant difference of $\mathrm{pH}$ value of samples was determined on some of the storage days $(\mathrm{p}<0.05)$. The $\mathrm{pH}$ value of samples have been no found difference statistical among groups ( $p>0.05)$ Researchers set $\mathrm{pH} 6.8$ as the consumable limit and consider fish with $\mathrm{pH}$ values 7 and above as stale, while some of them report that fish with a $\mathrm{pH}$ value above 7 th should be evaluated together with other characteristics, although it is common to be considered suspicious (Demirci and Orakl1, 1999). When looking at the $\mathrm{pH}$ value of the $\mathrm{RT}$ and the $\mathrm{pH}$ value of samples with treated the other oregano essential oil (RT1, RT2); the degradation rate of the fish samples slowed down on RT1; $3^{\text {th }}$ and RT2; 6th days thanks to the oregano essential oil (Figure 1). The low $\mathrm{pH}$ value slows down the degradation rate in samples with essential oil. it has stabilized the shelf life in a sense. In one study, the effect of $\mathrm{O}_{2}$ absorbent and oregano essential oil $(0.4 \% \mathrm{v} / \mathrm{w})$ on the $\mathrm{pH}$ value of rainbow trout fillets (O. mykiss) with the emergence of protein decomposition products, the $\mathrm{pH}$ decreased from the initial value of 6.65-6.09 and then increased (Mexis et al., 2009). pH value It is a defining parameter to prevent multiplying of unwanted microorganisms (Catarinoa et al., 2017). In our study, In the RT1 and RT2 values are 6.91-6-58 and $6.87-665$ between $0^{\text {th }}$ and $12^{\text {th }}$ days and a decrease has occurred even at low levels, which indicates that the shelf life is stable. Hosseini et al., (2016), stated that a lower increase in $\mathrm{pH}$ was observed (C, Fish Gelatin, Fish Gelatin+Oreganium:6.45-0. day; Fish Gelatin, Fish Gelatin+Oreganium:7.56-7.57 $7^{-1}$ 6.day) in trout samples with gelatin coating $(4 \%, \mathrm{w} / \mathrm{v})$ containing oregano (Origanum vulgare L.) essential oil $(1.2 \% \mathrm{w} / \mathrm{v})$. We think that the reason for the slow decrease of the $\mathrm{pH}$ value in trout samples is due to the use of only oreganum essential oil.

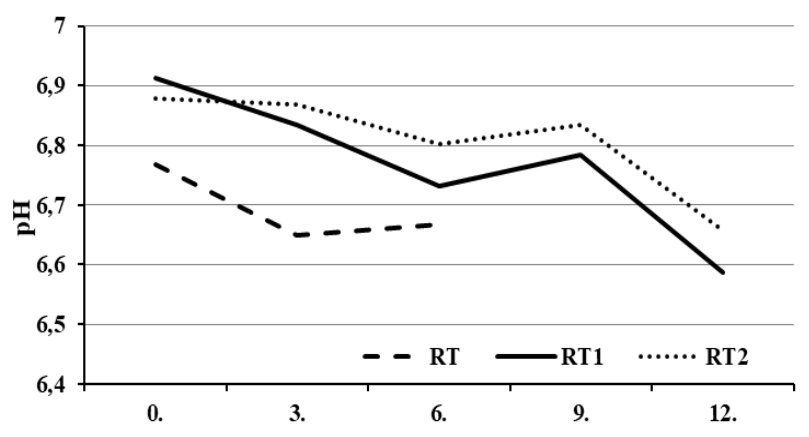

Figure 1. The $\mathrm{pH}$ Values of trout fillets (RT) and under stored in different rate oregano essential oil (RT, RT1, RT2). 
In the study of Boskovic et al. (2020), they stated that the bioactivity of essential oils varies at different $\mathrm{pH}$ values and can enter the cells more easily at low $\mathrm{pH}$. This means that the essential oil maintains its protective effect at low $\mathrm{pH}$.

The value of TBAs should not be less than 3 in a very high quality sample, and not more than 5 in a good sample. The consumable limit value is between 7 and 8 (Demirci and Orak, 1999). The TBA value reached its highest level after the 6th day in the control, and $4.16 \pm 0.50 \mathrm{mg} \mathrm{MA} \mathrm{kg}^{-1}$ on the $9^{\text {th }}$ day and after. From the $6^{\text {th }}$ day at RT1 to $3.23 \pm 0.56 \mathrm{mg}$ $\mathrm{MA} \mathrm{kg}^{-1}$, from the $9^{\text {th }}$ day at RT2, $3.33 \pm 1.33 \mathrm{mg} \mathrm{MA}$ $\mathrm{kg}^{-1}$ were at very good levels, and the fish samples that were left in the essential oil environment on the 12th day began to become stale (Figure 2).

Hosseini et al. (2016) stated that TBA values remained low between the 0th day and the $16^{\text {th }}$ day (0.01- $0.008 \mathrm{mg} \mathrm{MA} \mathrm{kg}^{-1}$ of flesh, in rainbow trout) and found that there was fluctuation during storage. In terms of TBA amounts, no significant differences were determined among the groups $(\mathrm{p}<0.05)$. Moreover, significant difference was determined between groups (RT and the other groups) on some of the measurement days $\left(1^{\text {th }}, 3^{\text {th }}\right.$, and $6^{\text {th }}$ days $)(\mathrm{p}<0.05)$. Karaton Kuzgun and Gürel İnanl, (2018), determined that combining thyme oil with chitosan and applying films of shelf life of luciobarbus esocinus fillets extended the by 33 days. And also they appears that TBA changes are similar to our study.

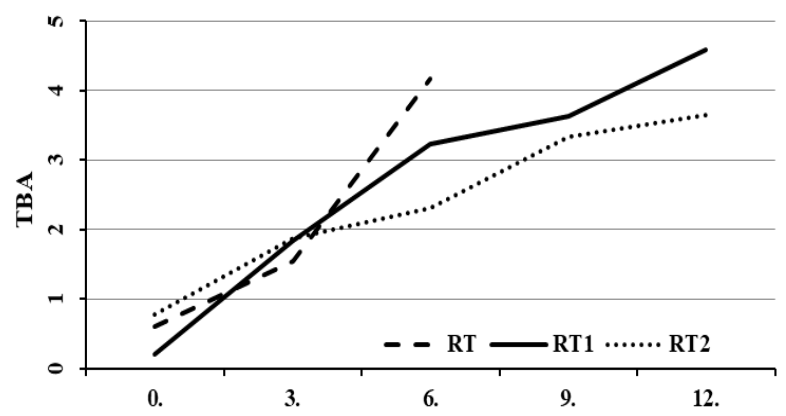

Figure 2. TBA mg MA kg-1 counts of trout fillets (RT) and under stored in different rate oregano essential oil (RT, RT1, RT2)

When looking at the relationship of oregano essential oil environment and day in TVB-N values (Figure 3), the highest value was observed in the

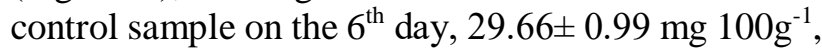

and on the $9^{\text {th }}$ and $12^{\text {th }}$ days at RT1 and RT2. Compared to the control with RT1 and RT2 groups, the reduction continued on day $3^{\text {th }}$ to $6^{\text {th }}$ in medium containing both oraegano essential oils.

Fish gelatin coating $(4 \%, \mathrm{w} / \mathrm{v})$ containing thyme (O. vulgare L.) essential oil $(1.2 \% \mathrm{w} / \mathrm{v})$ by Hosseini et al., (2016) under refrigerated storage $\left(4 \pm 1{ }^{\circ} \mathrm{C}\right)$ of rainbow trout $(O$. mykiss) examined; The TVB-N values we obtained were found to be higher. In the TVB-N values; A significant increase was observed for control samples after day 8th and for the other samples after day $16^{\text {th }}$. The significant differences in the TVB-N amounts of the samples was seen for day $6^{\text {th }}$ the control groups with the other groups $(\mathrm{p}<0.05)$. Moreover, an important difference was identified between the days checked $\left(0^{\text {th }}, 3^{\text {th }}\right.$, and $6^{\text {st }}$-all groups; $9^{\text {th }}$, and $12^{\text {rd }}$ days-RT1,RT2) $(\mathrm{p}<0.05)$. In terms of the data obtained from fish kept in RT1 and RT2, It was determined that RT1 is fresh and good between $0^{\text {th }}$ and $9^{\text {th }}$ days at RT2 on $0^{\text {th }}$ and $6^{\text {th }}$ days, and RT1 not exceeds consumable limits from $9^{\text {th }}$ and $12^{\text {th }}$ days on RT2. When our results are compared with the TVB-N values of Mexis et al., (2009), the highest TVB-N values of the samples with $0.4 \%$ w/v thyme essential oil and oxygen absorber added were between $10^{\text {th }}$ and $15^{\text {th }}$ days. Our TVB-N values with only essential oil added are the highest in RT1 and RT2 from $9^{\text {th }}$ and $12^{\text {th }}$ days. This has shown that oregano oil can be used without using oxygen absorbers, and it shows that using only oregano essential oil will positively affect the shelf life. According to the results of all these parameters, the consumption limit is between 3 and 6 days at RT 1 and 3 to 9 days at RT2.

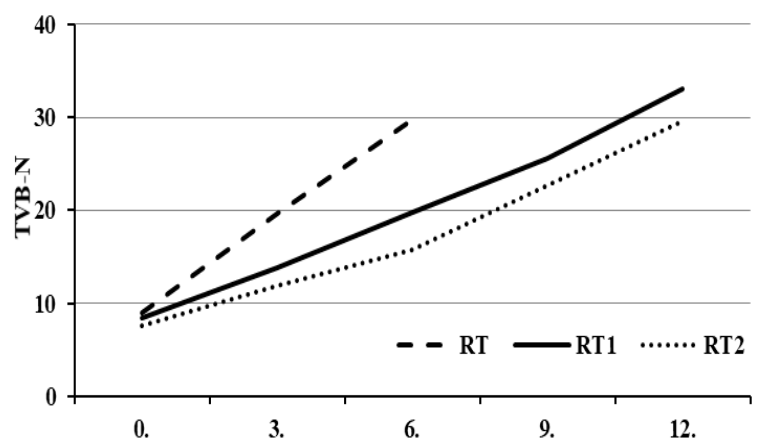

Figure 3. TVB-N mg $100 \mathrm{~g}^{-1}$ counts of trout fillets (RT) and under stored in different rate oregano essential oil (RT, RT1, RT2) 


\section{Organoleptic Assesment}

The organoleptic assesment of trout fillets under stored oregano essential oils is given in Figure 4. The scores obtained in the organoleptic assesment showed that the oregano essential oil treated samples (RT1, RT2) were generally acceptability as good by the panelists, whereas the samples without only essential oil were less acceptable in terms of their sensory properties. Accordingly, the demand rate of RT2 is up to the $9^{\text {th }}$ and $12^{\text {th }}$ days and RT1 is up to the $9^{\text {th }}$ day. RT1 $\left(8.60 \pm 0.49,0^{\text {th }}\right.$ on day) was demanded more due to the increase in the essential oil concentration. As a result, oergano oil has a positive effect on being preferred organoleptically. The significant differences in the generally acceptability points of the samples was observed for on day $3^{\text {th }}$ on day $6^{\text {th }}$ the control groups with the other groups $(p<0.05)$. Moreover, an important difference was observed between control days $(p<0.05)$. Thyme has also positively increased the sensory feature in trout samples due to its high aroma feature. A similar situation was observed in other studies due to this feature (Haute et al., 2017; Catarinoa, 2017).

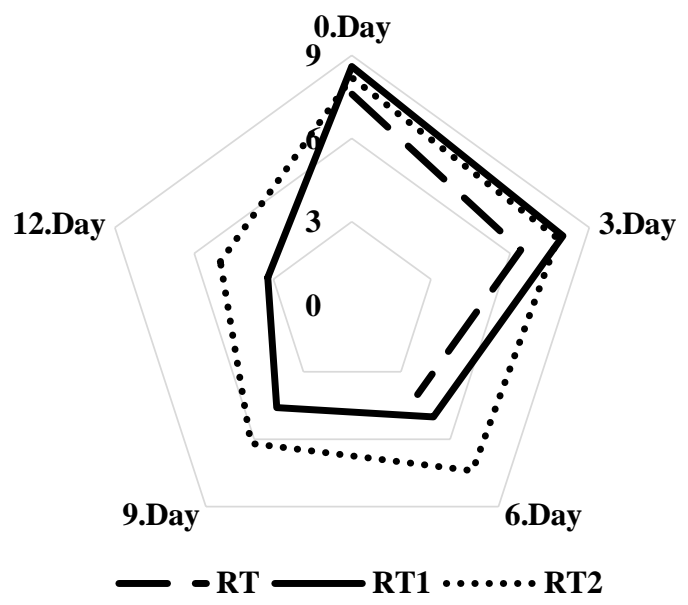

Figure 4. TVB-N mg 100g-1 counts of trout fillets (RT) and under stored in different rate oregano essential oil (RT, RT1, RT2)

\section{CONCLUSION}

In recent years, commercial essential oils have been of interest to reduce the growth of food spoilage microorganisms and natural foods that do not have toxic effects. Essential oils used to preserve the quality of fish and its products, which are a perishable food, stand out as they are used as a natural food preservative and do not carry a very high cost economically. As soon as the oregano essential oil dosage was too much, the positive effect on rainbow trout was further increased. In a sense, the shelf life is stabilized thanks to the oregano essential oil. Based on oregano essential oil application and day relationship, according to microbial load, sensory properties, $\mathrm{pH}, \mathrm{TVB}-\mathrm{N}$, TBA counts generally in trout samples (RT1, RT2) containing $1 \%$ and $2 \%$ oregano essential oil 3rd and 6th show good quality.

\section{CONFLICT OF INTEREST STATEMENT}

The author declares that there is no conflict of interest in this study.

\section{RESEARCH AND PUBLICATION ETHICS STATEMENT}

The author declares that the research and publication ethics are complied with in the study.

\section{REFERENCES}

AOAC, 2002. Official metods of analysis of the Association of Official Analytical Chemists, 17th edn. Association of Official Analytical Chemists, Gaithersburg.

Barreto, T.A., Andrade, S.C.A., Maciel, J.F., Arcanjo, N.M.O. Madruga, M.S., Meireles, B., Cordeiro, Â.M.T., Souza E.L., Magnani, M., 2016. A Chitosan coating containing essential oil from Origanum vulgare L. to control post harvest mold infections and keep the quality of cherry tomato fruit. Frontiers in Microbiology, 7:1714-1724

Boskovic, M. Djordjevic, J. Glisic, M. Ciric, J. Janjic, J. Zdravkovic, N. Krnjaic, D. Milan Baltic, Z., 2020. The effect of oregano (Origanum vulgare) essential oil on four Salmonella serovars and shelf life of refrigerated pork meat packaged under vacuum and modified atmosphere. Journal of Food Processing and Preservation, 44:14311.

Botsoglou, N.A. Fletouris, D.J. Florou-Paneri, P. Christaki, E. Spais, A.B., 2003. Inhibition of lipid oxidation in long-term frozen stored chicken meat by dietary oregano essential oil and a-tocopheryl acetate supplementation. Food Research International, 36:207-213.

Cardoso, L. G., Santos, J. C. P., Camilloto, G. P., Miranda, A. L., Druzian, J. I., Guimarães, A. G., 2017. Development of active films poly (butylene adipate co-terephthalate) - PBAT incorporated with oregano essential oil and application in fish fillet 
preservation. Industrial Crops \& Products, 108:388397.

Carmo, E. S. Lima, E.O., Souza, E. L., 2008. The Potential Of Origanum vulgare L. (Lamiaceae) Essential Oil In Inhibiting The Growth Of Some Food-Related Aspergillus species. Brazilian Journal of Microbiology, 39:362-367.

Catarinoa, M. D. Alves-SilvabcRui J. M. Fernandes P. JoséGonçalves M., Salgueiroc L.R., F.Henriques M., Cardoso, S.M., 2017. Development and performance of whey protein active coatings with Origanum virens essential oils in the quality and shelf life improvement of processed meat products. Food Control, 80:273-280

Conell, J.J, Shewan, J.M., 1979. Past, present and future fish science. In: Advances in fish science and technology. Fishing News Books Ltd., England.

Demirci, M., Orak H.H., 1999. Farklı soğutma ortamları ve $-12{ }^{\circ} \mathrm{C}$ 'de depolanan istavrit balığında (Trachurus trachurus) meydana gelen kalite değişimleri. Turkish Journal of Agriculture and Forestry, 23:143-150.

Fraj, A., Jaâfar, F., Marti, M., Coderch, L., Ladhari, N., 2019. A comparative study of oregano (Origanum vulgare L.) essential oil-based polycaprolactone nanocapsules/ microspheres: Preparation, physicochemical characterization, and storage stability. Industrial Crops \& Products, 140:111669.

Goulas, A. E., Kontominas. M. G., 2007. Combined effect of light salting, modified atmosphere packaging and oregano essential oil on the shelf-life of sea bream (Sparus aurata): Biochemical and sensory attributes. Food Chemistry, 100:287-296.

Gurdian, C., 2015. Evaluation of whey-protein-isolate edible films containing oregano (Origanum vulgare) essential oil to improve shelf life of cheeses during refrigerated storage. The Department of Nutrition and Food Sciences, Zamorano University, Honduras, $128 \mathrm{p}$.

Harrigan, W.F., 1998. Laboratory methods in food microbiology, 3rd edn. Academic Press, London.

Haute, S. V., Raes, K., Devlieghere, F., Sampers, I., 2017. Combined use of cinnamon essential oil and MAP/vacuum packaging to increase the microbial and sensorial shelf life of lean pork and salmon. Food Packaging and Shelf Life, 12:51-58.

Hosseini, S.F., Rezaei, M., Zandi, M., Ghavi, F., 2016. Effect of fish gelatin coating enriched with oregano essential oil on the quality of refrigerated rainbow trout fillet. Journal of Aquatic Food Product Technology, 25:6, 835-842.

ICMSF (International Commisson on Microbiological Spescifications for Foods), 1986. Microorganisms in Foods 2. sampling for microbiological analysis, $2^{\text {nd }}$ edition, University of Toronto Press, Toronto.
Karabagias, I.. Badeka, A., Kontominas, M.G., 2011. Shelf life extension of lamb meat using thyme or oregano essential oils and modified atmosphere packaging. Meat Science, 88:1, 109-116.

Karaton Kuzgun, N., Gürel Inanl,, A., (2018). The investigation of the shelf life at $2 \pm 1{ }^{\circ} \mathrm{C}$ of Luciobarbus esocinus fillets packaged with films prepared with the addition of different essential oils and chitosan. Journal of Food Science and Technology, 55, 2692-2701.

Klein, G., Rüben, C., Upmann, M., 2013. Antimicrobial activity of essential oil components against potential food spoilage microorganisms. Curr Microbiol 67:200-208.

Lawless, H.T., Heymann, H., 2010. Sensory Evaluation of Food, Second Edition, Springer.

Mexis, S.F., Chouliara, E., Kontominas, M.G., 2009. Combined effect of an oxygen absorber and oregano essential oil on shelf life extension of rainbow trout fillets stored at $4^{\circ} \mathrm{C}$. Food Microbiology, 26:598-605.

Tarladgis, B.G., Watts, B.M., Younathan, M.T., Dugan, J.R., 1960. A distillation method for the quantitative determination of malonaldehyde in racid foods. Journal of the American Oil Chemists' Society, 3:44 48.

Teixeira B, Marques A, Pires C, et al. 2014. Characterization of fish protein films incorporated with essential oils of clove, garlic and origanum: Physical, antioxidant and antibacterial properties. LWT-Food Science and Technology, 59(1):533-539. 